\title{
Prolapse of Intussusception through the Anus as a Result of Sigmoid Colon Cancer
}

\author{
Hiroki Ochiai ${ }^{a, c}$ Takashi Ohishi ${ }^{a}$ Shikou Seki ${ }^{a}$ \\ Jo Tokuyama ${ }^{a}$ Koji Osumi ${ }^{a}$ Hidejirou Urakamia \\ Atsushi Shimada ${ }^{a}$ Akira Matsui $^{a}$ Yoh Isobe $^{a}$ \\ Yuya Murata $^{\mathrm{b}}$ Takashi Endo $^{c}$ Yoshiyuki Ishiic $^{\mathrm{c}}$ \\ Hirotoshi Hasegawac Sumio Matsumoto ${ }^{a}$ Yuko Kitagawac \\ Departments of aSurgery and bathology, National Tokyo Medical Center, and \\ 'Department of Surgery, Keio University School of Medicine, Tokyo, Japan
}

\section{Key Words}

Adult intussusception · Sigmoid colon cancer · Surgery

\begin{abstract}
Adult intussusception is rare and most often associated with cancer. We report a case of intussuscepted sigmoid colon into the rectum protruding from the anus of a 47-year-old woman. The cause of the intussusception was sigmoid colon cancer. We removed the intussuscepted part of the sigmoid colon as well as the rectum and regional lymph nodes. The patient recovered uneventfully and there has been no evidence of recurrence of the cancer.
\end{abstract}

\section{Introduction}

Intestinal intussusception is relatively common in children, whereas in adults it is a rare clinical entity, which occurs most often secondary to a defined pathologic abnormality [1]. Although surgical resection is recommended, there is still no consensus regarding optimal management of adult intussusception caused by intestinal cancer. Considering the theoretical risk of perforation, which could cause seeding of tumor cells and the release of microorganisms into the intraabdominal cavity, most surgeons advocate en bloc resection without reduction [1-4]. However, less invasive management may be indicated and laparoscopy appears to be an attractive alternative to laparotomy for selected patients $[5,6]$. We describe how we performed an emergency laparotomy for adult colonic intussusception caused by sigmoid colon cancer. The successful reduction 


\begin{tabular}{r|l|l|l}
$\begin{array}{r}\text { Case Reports in } \\
\text { Gastruanteriology }\end{array}$ & $\begin{array}{l}\text { Case Rep Gastroenterol 2010;4:346-350 } \\
\text { DOI: 10.1159/000320770 }\end{array}$ & $\begin{array}{l}\text { Published online: } \\
\text { September 15, 2010 }\end{array}$ & $\begin{array}{l}\text { O 2010 S. Karger AG, Basel } \\
\text { ISSN 1662-0631 } \\
\text { www.karger.com/crg }\end{array}$ \\
\hline
\end{tabular}

allowed us to treat the extensive intussusception with a more limited anterior resection instead of en bloc wide abdominoperineal resection.

\section{Case Report}

A 47-year-old woman was admitted to our emergency department with sudden and severe abdominal cramping pain after suffering repeated episodes of colicky and intermittent abdominal pain for about 1 week. On physical examination, the abdomen was soft but mildly distended. There was upper abdominal tenderness without rebound. The results of laboratory investigations were normal including tumor markers of carcinoembryonic antigen and CA19-9. Plain abdominal radiography showed a distended colon and digital rectal examination revealed a protuberant mass-like lesion with a smooth surface. As computed tomography (CT) scans indicated a target mass (fig. 1), sigmoid-rectum intusussception caused by sigmoid colon cancer was diagnosed.

At surgery, the sigmoid colon was found to be intussuscepted into the rectum very close to the anus, making reduction difficult. After dividing the peritoneum, the surgeon inserted his hands below the peritoneal reflection along the rectum and pushed the intussusception back from the distal to the proximal rectum using a milking action (ig. 2 ). The rectum was divided $5 \mathrm{~cm}$ from the peritoneal reflection using a stapler, and the sigmoid colon was divided $10 \mathrm{~cm}$ proximal from the intussusception. We removed the intussuscepted part of the colon as well as the rectum, intermediate lymph nodes, and regional lymph nodes, and performed an anterior resection. The patient had an uneventful postoperative course.

Macroscopically, the surgical specimen contained a $3 \mathrm{~cm}$ protuberant tumor. The intestinal wall was edematous but not necrotic. Histological examination revealed well-differentiated adenocarcinoma with invasion of the muscularis propriae ( $\underline{\text { fig. }}$ ) ). The lymph nodes were negative for cancer cells. At present, three year after surgery, she is free of symptoms and she has had an uneventful course.

\section{Discussion}

Intussusception is a major cause of intestinal obstruction in children, but it is relatively unusual in adults. Adult intussusception accounts for only $1 \%$ of all bowel obstructions, $5 \%$ of all intussusceptions, and $0.0003-0.020 \%$ of all hospital admissions [1]. Few general surgeons encounter more than one or two adult patients with colon intussusception during their careers, and most cases are undiagnosed before laparotomy. Intussusception of the sigmoid colon is often misdiagnosed as a large polyp [7] or rectal prolapse [4]. However, a delay in diagnosis could result in death, so surgeons must be aware of the possibility of this type of intussusception if they find an unusual rectal tumor in a patient with intestinal obstruction.

Our patient presented with sudden and severe abdominal pain, after a short history of repeated episodes of colicky and intermittent abdominal pain. Although abdominal pain is the most common symptom, colonic intussusception can also manifest as a variety of acute, intermittent or chronic symptoms, making its preoperative diagnosis difficult. Ultrasonography has been used to evaluate suspected intussusception [8] and findings include the target and doughnut signs on the transverse view and the pseudokidney sign on the longitudinal view. The major limitation of ultrasonography in evaluating acute intestinal obstruction is the presence of air in the bowel, which results in poor transmission and difficulties in interpreting the image [2]. The characteristic CT findings of intussusception include an early target mass with enveloped, eccentrically located areas of low density. Recent papers report that CT is the most accurate imaging modality for diagnosing intussusception. The characteristic appearance of intussusception on barium 


\begin{tabular}{r|l|l|l} 
Case Reports in & $\begin{array}{l}\text { Case Rep Gastroenterol 2010;4:346-350 } \\
\text { DOI: 10.1159/000320770 }\end{array}$ & $\begin{array}{l}\text { Published online: } \\
\text { September 15, 2010 }\end{array}$ & $\begin{array}{l}\odot \text { 2010 S. Karger AG, Basel } \\
\text { ISSN 1662-0631 } \\
\text { www.karger.com/crg }\end{array}$ \\
Gastualteroloyy
\end{tabular}

enema is a cup-shaped filling defect with a spiral or coil-spring appearance. The CT findings proved helpful in establishing the preoperative diagnosis in our patient [4].

For patients with intussusception and an inflamed, ischemic or friable bowel wall, it is advisable not to attempt operative reduction, but to proceed with resection. Given the likelihood of malignancy, most cases of colo-colonic intussusception should be resected en bloc without reduction, which should be avoided because it may result in the spread of malignant cells $[2,4]$. Even when a benign tumor is suspected before surgery, careful manipulation is mandatory to avoid perforating the strangulated bowel with poor stability. According to Nagorney et al., abdominoperitoneal resection is indicated when the lower rectum is removed [3]. Lynn and Agrez reported a case of sigmoid colon intussusception in whom the rectum was opened circumferentially with diathermy at the point of the intussusception, and the intussuscepted sigmoid colon was delivered out of the rectum through the anus [9]. However, this procedure would cause contamination of the abdominal cavity. In our case, the peritoneal incision was clean and allowed us to deliver the sigmoid colon out of the rectum, whereby abdominoperineal resection was avoided $[3,4]$.

Laparoscopic surgery is now widely used for the resection of benign and malignant gastrointestinal tumors; however, its application for intussusception is still controversial. Kirshtein et al. reported that a laparoscopic approach is safe and effective for most cases of small bowel obstruction and recommended its use as the first-line treatment [5]. Chiu et al. described the successful laparoscopic resection of ileocolic intussusception caused by primary ileal lymphoma [6].

The usefulness of laparoscopic surgery in emergency situations, particularly for non-decompressed intestinal obstruction, remains controversial because adequate intraperitoneal visualization is almost impossible in such cases. In our case, the small and large bowel were so dilated that laparoscopic manipulation would have been difficult. The choice of a laparoscopic or open approach depends on the clinical condition of the patient, the location and extent of the intussusception, the possibility of underlying disease, and whether the surgeon has sufficient laparoscopic expertise. Additional reports may help to standardize the management of this uncommon disease. 


\begin{tabular}{r|l|l|l}
$\begin{array}{r}\text { Case Reports in } \\
\text { Gastroenterology }\end{array}$ & $\begin{array}{l}\text { Case Rep Gastroenterol 2010;4:346-350 } \\
\text { DOl: 10.1159/000320770 }\end{array}$ & $\begin{array}{l}\text { Published online: } \\
\text { September 15, 2010 }\end{array}$ & $\begin{array}{l}\text { O 2010 S. Karger AG, Basel } \\
\text { ISSN 162--0631 } \\
\text { www.karger.com/crg }\end{array}$ \\
\hline
\end{tabular}

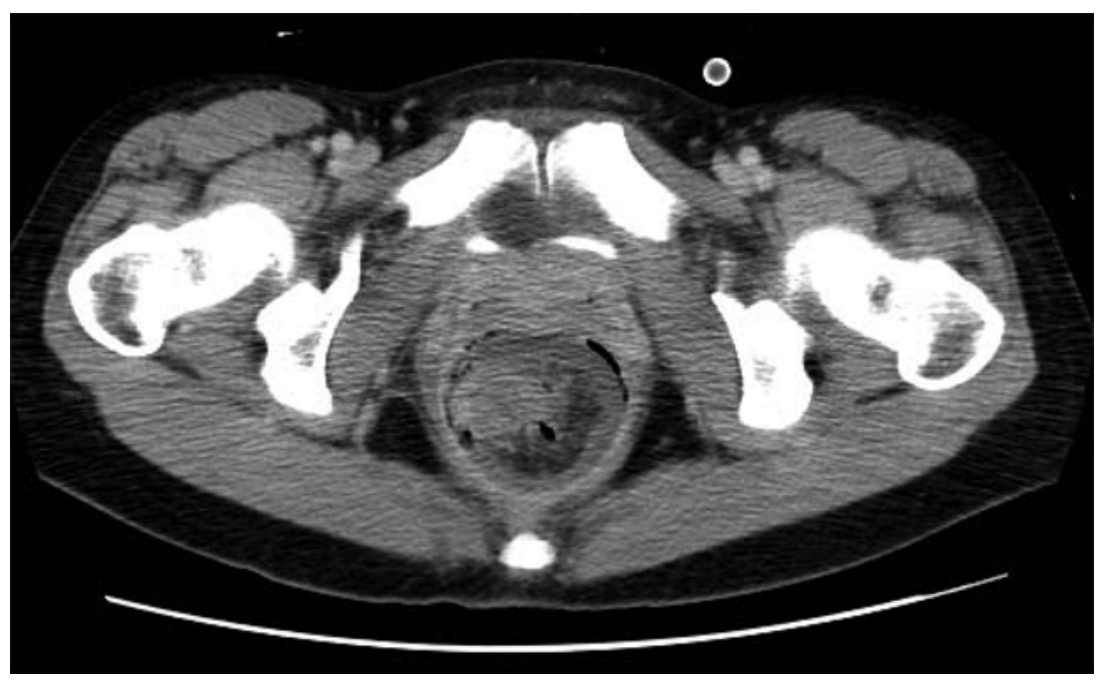

Fig. 1. CT scans of the abdomen showed enlargement of the colorectal wall, fat within the intussusception, and air within the intussuscipiens.

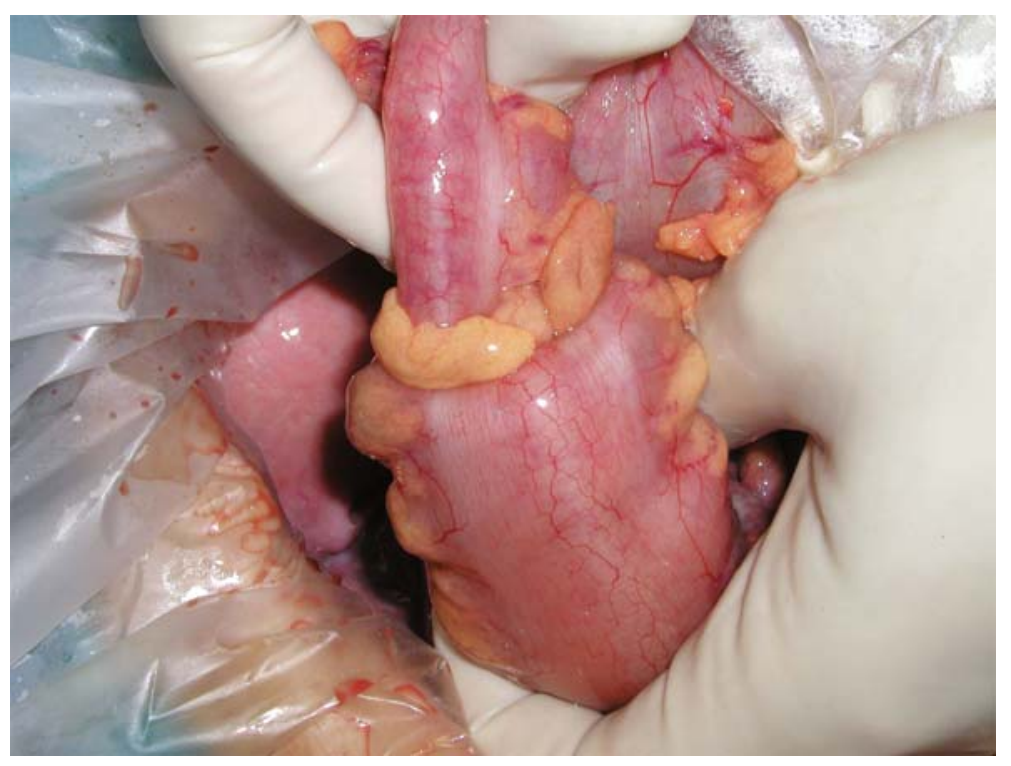

Fig. 2. At surgery the sigmoid colon was found to be intussuscepted into the rectum very close to the anus. 


\begin{tabular}{r|l|l|l} 
Case Reports in & $\begin{array}{l}\text { Case Rep Gastroenterol 2010;4:346-350 } \\
\text { DOI: 10.1159/000320770 }\end{array}$ & $\begin{array}{l}\text { Published online: } \\
\text { September 15, 2010 } 010 \text { S. Karger AG, Basel }\end{array}$ & $\begin{array}{l}\odot \text { ISSN 1662-0631 } \\
\text { www.karger.com/crg }\end{array}$ \\
Gastualteroloyy
\end{tabular}

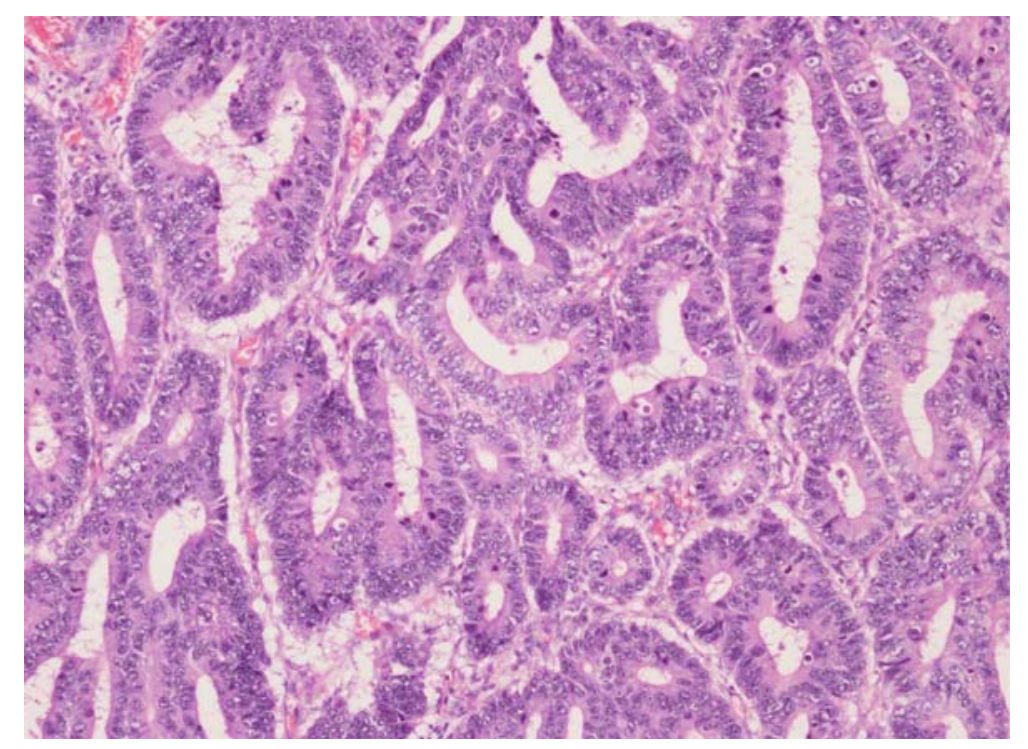

Fig. 3. Histological examination revealed well-differentiated adenocarcinoma with invasion of the muscularis propriae (magnification $\times 100$ ).

\section{References}

1 Eisen LK, Cunningham JD, Aufses AH Jr: Intussusception in adults: institutional review. J Am Coll Surg 1999;188:390-395.

2 Begos DG, Sandor A, Modlin IM: The diagnosis and management of adult intussusception. Am J Surg 1997;173:88-94.

3 Nagorney DM, Sarr MG, McIlrath DC: Surgical management of intussusception in the adult. Ann Surg 1981;193:230-236.

4 Yalamarthi S, Smith RC: Adult intussusception: case reports and review of literature. Postgrad Med J 2005;81:174-177.

5 Kirshtein B, Roy-Shapira A, Lantsberg L, Avinoach E, Mizrahi S: Laparoscopic management of acute small bowel obstruction. Surg Endosc 2005;19:464-467.

6 Chiu CC, Wei PL, Huang MT, Wang W, Chen TC, Lee WJ: Laparoscopic treatment of ileocecal intussusception caused by primary ileal lymphoma. Surg Laparosc Endosc Percutan Tech 2004;14:93-95.

-7 Fujino Y, Fujio Y, Shimada E, Okazaki A: Intussusception due to vanishing colon cancer with metastasis of the regional lymph nodes: report of a case. Surg Today 2000;30:188-190.

-8 Lorenzi M, Iroatulam AJ, Vernillo R, Banducci T, Mancini S, Tiribocchi A, Ferrari FS, Mancini S: Adult colonic intussusception caused by malignant tumor of the transverse colon. Am Surg 1999;65:11-14.

-9 Lynn M, Agrez M: Management of sigmoid colon intussusception presenting through the anus. Aust N Z J Surg 1998;68:683-685. 